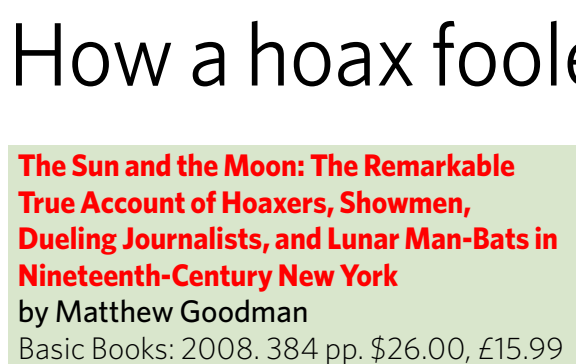

In the hot summer of 1835, Matthew Goodman writes in his new book The Sun and the Moon, an English-educated journalist who had moved to New York mulled over his adopted country. Although there was much that was admirable about the nation, he decided, a blind obedience to religion was keeping it from being as rational as he wished it to be. Being a superior sort of individual, and confident that he was better educated than those around him, he resolved to fix that.

The problem was most painful, he felt, in astronomy, which was especially popular that year. Halley's comet was expected back in September, and already in August telescopes had been set up in public parks to offer citizens a first glimpse for 6 cents. Yet, instead of the predictable nature of the comet's return demolishing religious obedience, as popular science writer Richard Dawkins might have wished, public opinion was just the opposite.

Halley's comet, it was believed, proved the existence of a divine Creator, who was able to propel objects at will through the heavens. New Yorkers - educated and not - accepted that intelligent beings existed on other planets, providing further proof that a divine creator beneficently ruled over us all.

That link between astronomy and religion was what Richard Adams Locke, a descendant of the philosopher John Locke, decided had to be changed. He knew that the founding fathers of the United States had been critical of revealed religion - indeed, during his own education in Britain he had come to agree with that criticism. Before his arrival in New York he had looked to the United States as a beacon of radical reform, suitable to inspire class-bound,

ed the faithful

subservient Britain. Yet now his adopted country was in the grip of religious fundamentalism.

After several years of making his way in journalism, Locke was in a position to act. He had recently been promoted from police reporter to editor-in-chief of the New York Sun, one of the world's first massmarket newspapers. It was aimed at ordinary readers, produced on new, steam-driven presses, and sold not by genteel subscription but by hustling newspaper boys.

Late in August 1835 , a series of articles began appearing in the newspaper.

They described the wondrous discoveries of John Herschel, the noted English astronomer who had gone to the Cape provinces, in what is now South Africa, to chart the southern sky. Herschel was indeed there, but being so remote he was also many weeks away from any direct communication with New York. This made him an especially good subject for an inventive journalist. The hoax that Locke conjured up would have a long stretch to run before it could be disproved.

The first few Sun articles were innocuous enough, stating that a scientific journal was reporting some astounding results before going into technical detail about the improved telescope that Herschel was using.

Then came the bombshell: Herschel, it was reported, had discovered lakes of water and herds of wild animals on the Moon. Circulation of the Sun shot up. More reports came in. Herschel had discovered more than animals he had identified human-like life there as well.

\section{Bad Science}

by Ben Goldacre

(HarperCollins, E12.99)

Fast-paced and highly readable, Bad Science dismantles the dubious claims behind scare headlines, fad nutritionists and suspect 'clinical trials'. Looking at specific cases, Ben Goldacre explains how bad science is presented to look real and why people are so willing to believe it.

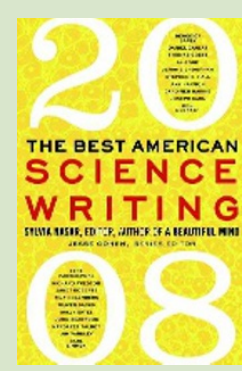

The newsboys selling the Sun might not have read the articles in detail, but they loved the circulation they generated. Everyone - clerics and engineers, government officials and labourers - wanted to know what was going to come next.

Locke didn't disappoint them. For shortly before the great southern African telescope needed to be, conveniently, repositioned for other pressing enquiries, Herschel managed to detect clear marks of religious temples on the Moon.

By Locke's plan, that would end it. He had taken the purported discoveries to ridiculous extremes. Everyone would realize he was writing a spoof, and Americans would see how silly it was to use astronomy as a way of justifying their religious beliefs.

But English journalists who think they know the United States have a habit of getting things wrong. Even when reports came back
The Best American Science Writing 2008

Edited by Sylvia Nasar (series edited by Jesse Cohen) (Harper Perennial, \$14.95)

The latest edition of this popular series offers a selection of excerpts from familiar names, including Oliver Sacks and Carl Zimmer. Some focus on climate change or new technology. Many deal with medicine or disease - from genetic disorders, psychiatry and cancer, to compromised physicians and misinterpreted research. 
from South Africa that Herschel had made no such discoveries as the Sun described, good New Yorkers were only reinforced in their religious beliefs. Surely the visions that he had described were a sign of the religious insights that would await us, once science moved forward enough?

The Sun and the Moon is a wonderful cautionary tale, especially in an era like our own, when, for example, no candidate is likely to be elected president of the United States if he professes disbelief in either science or religion. The mix seems illogical, but only if one misses how the two domains are popularly understood. Most people do not understand the details of how science works. They just see the impressive results of what it can achieve - whether it is steam engines in Locke's era or iPhones in ours. The more technology advances, the more such blind trust is encouraged. Locke and Dawkins might well weep, but a popular life that shares none of their ultimate views goes on.

Unfortunately, Goodman tells the story poorly, undecided if his book is an account of Locke's hoax or a general social history of the mass press and ways that cynics and reformers dealt with popular credulity. But his research is excellent, and if publishers fund him to write a wider account, it would be well worth reading.

David Bodanis is a writer based in London and the author of Passionate Minds.

\section{Tale of a clockwork computer}

\section{Decoding the Heavens: Solving the Mystery of the World's First Computer \\ by Jo Marchant \\ William Heinemann/Da Capo Press: 2008/2009. 330 pp/288 pp. £12.99/\$25}

It is appropriate that Arthur C. Clarke recommended this book before his death in March 2008. Decoding the Heavens tells the story of the 2,000-year-old Antikythera Mechanism and its decipherment. The tale encompasses diving, shipwrecked treasure, scientific puzzles, cutting-edge technology and computing, all of which Clarke knew from the inside. Moreover, he had a walk-on role.

The Antikythera Mechanism is an ancient Greek artefact comprising more than 30 precisely cut bronze gear wheels, dials and pointers held in a wooden case.

Clarke began to publicize the mechanism in 1959, perhaps encouraged by his friend Jacques Cousteau, who in 1953 had reinvestigated an ancient shipwreck off the Greek island of Antikythera, which had been salvaged by roving Aegean sponge divers in 1900-01. In 1965, Clarke tracked down the mechanism's encrusted remains languishing in a cigar box at the National Archaeological Museum in Athens, later televising it in Arthur C. Clarke's Mysterious World in 1980. If the ancient Greeks had been able to build on the knowledge required to make the mechanism, he told a Smithsonian
Institution audience in 1973, by now humans might be exploring the nearer stars, not merely the inner Solar System.

Yet, as Clarke admits on the book's jacket, the Antikythera Mechanism remains "underrated". The instrument was known only to a small circle of enthusiasts until a paper was published in 2006 explaining its operation, based on X-ray images of the interior and a new technique for illuminating previously hidden surface inscriptions (T. Freeth et al. Nature 444, 587-559; 2006). Jo Marchant, then a Nature staff journalist, wrote a news feature to accompany the paper, and the book grew from her research. Decoding the Heavens is Marchant's first book and is aimed squarely at the non-scientific reader, but is serious about the science. Her gripping and varied account will propel the mechanism to greater fame, although it may never achieve the celebrity of the Rosetta Stone that it probably deserves.

The complexity of the mechanism suggests that the ancient Greeks had achieved a level of clockwork technology not reached again until the Industrial Revolution of the eighteenth century. "It's hard to overestimate the uniqueness of the find. Before the Antikythera Mechanism, not one gearwheel had ever been found from antiquity, nor indeed any example of an accurate pointer or scale. Apart from the Antikythera Mechanism, they still haven't," Marchant explains.

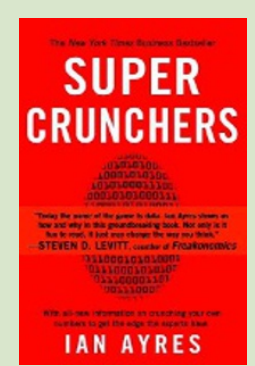

\section{Super Crunchers}

\section{by lan Ayres}

(Bantam Books, \$14.00)

Ayres explains how data mining, statistics and number crunching are used increasingly by everyone and everything from Internet search engines to your family physician. Showing how this affects people directly, he gives advice on how to defend ourselves against the negative sides of this data blitz.

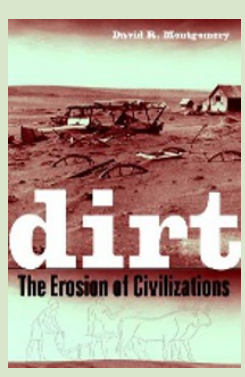

Dirt: The Erosion of Civilizations

by David Montgomery

(Univ. California Press, \$16.95)

Montgomery explains how the collapse of ancient civilizations is linked to soil erosion and shows that this can be seen today. "Societies prosper and persist best when they figure out ways to keep their soil where it belongs and not treat it as if it were dirt cheap," wrote Eric A. Davidson (Nature 447, 777-778; 2007). 